\title{
PENGARUH PERCEIVED SUPPORT, FEAR OF FAILURE DAN SELF-EFFICACY TERHADAP NIAT BERWIRAUSAHA PADA MAHASISWA S1 MANAJEMEN FAKULTAS EKONOMI DAN BISNIS UNIVERSITAS AIRLANGGA
}

\author{
Jovi Sulistiawan \\ Departemen Manajemen Fakultas Ekonomi dan Bisnis, UniversitasAirlangga \\ E-mail: jovisulistiawan@yahoo.com
}

\begin{abstract}
The imbalance between job seekers and job opportunities cause an increase of unemployment rate in Indonesia. Thus make Universities try to increase entrepreneurship intention among students. Universities try to give support such as giving entrepreneurship education to students. This research examines whether entrepreneurship education has positive effects on entrepreneurial intention. Besides, this research examines whether attitudes towards entrepreneurship, perceived support and also fear of failure have effects on entrepreneurial intention among students. The data was collected using questionnaire instrument obtained from 254 respondents of Students of Management, Faculty of Economics and Business Airlangga University in Surabaya. The results of this study are expected to give some input for the University to increase the entrepreneurial intention among students.
\end{abstract}

Keyword(s) : Entrepreneurship, Entrepreneurial Intention, Fear of Failure, Perceived Supports

\section{PENDAHULUAN}

Dalam beberapa waktu terkahir ini, tingkat pengangguran di Indonesia mengalami kenaikan. Banyak sebab yang melatarbelakangi kenaikan jumlah pengangguran di Indonesia, salah satunya adalah krisis keuangan global. Meskipun secara jumlah mengalami penurunan namun mengalami kenaikan secara agregat. Kurangnya lapangan pekerjaan untuk menampung jumlah lulusan perguruan tinggi, diperlukan solusi yang cepat dan efektif. Salah satunya adalah dengan mendorong timbulnya niat kewirausahaan pada diri mahasiswa. Dengan menanamkan pentingnya niat kewirausahaan pada mahasiswa, para mahasiswa akan didorong untuk menciptakan ide-ide baru, pengembangan teknologi, dan 


\section{Jovi Sulistiawan}

inovasi-inovasi di berbagai bidang sehingga mampu berkompetisi dan menciptakan kesempatan kerja bagi diri sendiri dan masyarakat.

Berdasarkan data dari BPS mengenai tingkat pengangguran menurut pendidikan tinggi yang ditamatkan, penyumbang terbesar angka pengangguran di Indonesia berasal dari tamatan SMA (Umum dan Kejuruan) berkisar 3-5 juta, namun mengalami penurunan dari tahun ke tahun. Pada bulan februari 2014 lalu BPS melansir data bahwa tingkat pengangguran di Indonesia di bawah $6 \%$ atau turun dari tahun sebelumnya yang mencapai 7\%. Hal tersebut bisa disebabkan oleh beberapa hal, salah satunya adalah semakin banyaknya dukungan baik dari pemerintah ataupun institusi pendidikan yang mendukung warganya untuk melakukan wirausaha.

Dukungan dari institusi baik institusi pendidikan maupun pemerintah akan mempengaruhi niat seseorang untuk melakukan wirausaha. Seperti yang dijelaskan oleh Byabashaija dan Katono (2011) bahwa dukungan dari pihak-pihak yang dianggap penting akan mampu untuk meningkatkan niat seseorang dalam melakukan wirausaha. Hal yang sama juga dikemukakan oleh Saeed, Muffatto, dan Yousafzai (2014) bahwa ketika seseorang mendapatkan dukungan baik itu berupa pengetahuan, finansial, serta dukungan dari orang-orang yang ada di sekitarnya, akan berdampak pada semakin tertariknya orang tersebut untuk memiliki niat berwirausaha.

Disamping itu, dukungan yang dirasakan akan memotivasi seseorang untuk semakin yakin dengan kemampuannya. Keyakinan seseorang bahwa mereka dapat menyelesaikan tugasnya dengan baik adalah konsep self efficacy (Carr dan Sequeria 2007). Byabashaija dan Katono (2011) menyatakan bahwa dukungan yang dirasakan oleh seseorang akan membuat orang tersebut memiliki kepercayaan diri untuk melakukan sesuatu semakin meningkat. Semakin meningkatnya self-efficacy seseorang dalam berwirausaha maka semakin tinggi pula niatnya untuk berwirausaha (Saeed dkk. 2014).

Menjadi seorang wirausaha menuntut seseorang untuk menjadi risk-taker. Jika seseorang masih takut untuk mengambil risiko maka orang tersebut masih takut jika suatu saat usahanya mengalami kegagalan. Ketakutan akan kegagalan inilah yang menjadi faktor penghambat seseorang untuk berwirausaha. Seperti yang dikemukakan oleh Shinnar, Giacomin dan Janssen (2012) bahwa takut akan kegagalan membuat seseorang menjadi ragu untuk berwirausaha. 
Penelitian ini berusaha untuk menguji pengaruh perceived support terhadap self-efficacy, serta pengaruh perceived support dan self-efficacy terhadap niat seseorang untuk berwirausaha. Kemudian akan diuji pula bagaimana pengaruh ketakutan akan kegagalan atau fear of failure terhadap niat untuk berwirausaha. Penelitian ini menggunakan mahasiswa sebagai objek penelitian karena pada saat itulah mahasiswa berada dalam tahapan untuk memilih karir yang sesuai bagi mereka (Shinnar dkk. 2012)

\section{LANDASAN TEORI DAN HIPOTESIS}

\section{Perceived Support}

Dukungan yang dirasakan seseorang bisa berasal dari lingkungan sekitar individu. Shinnar, dkk (2012) menyatakan bahwa dukungan yang dirasakan adalah dukungan dari beberapa pihak untuk mendukung seseorang menjadi seorang pengusaha. Lebih lanjut, Shinnar dkk (2012) menyatakan bahwa dukungan tersebut bisa berupa dukungan dari pemerintah, dukungan dari keluarga serta dukungan atau kemudahan untuk mendapatkan modal.

Dukungan juga bisa berasal dari pihak universitas. Mengingat saat ini banyak sekali universitas yang memiliki kurikulum tentang kewirausaahan maka hal tersebut juga dapat meningkatkan niat mahasiswa untuk berwirausaha.

\section{Fear of failure}

Takut akan kegagalan adalah suatu hal yang menjadi penghambat seseorang untuk berwirusaha (Shinnar dkk. 2012). Karakteristik pribadi seseorang juga dapat menentukan tingkat besar atau kecilnya ketakutan akan kegagalan, semakin seseorang bersifat menghindari risiko maka semakin besar pula ketakutan akan kegagalan. Ketakutan akan kegagalan dalam konteks penelitian ini adalah takut apabila suatu saat usaha yang dirintisnya tidak bisa berjalan dengan baik atau berhenti di tengah jalan.

\section{Entrepreneurial Self-Efficacy}

Self-efficacy adalah tingkat keyakinan seseorang mengenai kemampuan yang dimilikinya (Sequeria, Mueller dan McGee 2006). Self-efficacy merepresentasikan atau mencerminkan mengenai suatu keyakinan pada seseorang bahwa mereka dapat menyelesaikan tugasnya 


\section{Jovi Sulistiawan}

dengan baik (Carr dan Sequeria 2007). Entrepreneurial self-intention merupakan tingkat atau derajat di mana individu meyakini bahwa dirinya mampu tugas dan peran sebagai seorang pengusaha.

\section{Entrepreneurial Intentions}

Intentions diasumsikan sebagai suatu variabel yang dapat memprediksi faktor-faktor motivasional yang berpengaruh terhadap behavior atau perilaku (Ajzen 1991). Intentions adalah indikator-indikator seberapa keras usaha seseorang untuk melakukan suatu tindakan (Ajzen 1991 dalam Kolvereid 1997).

Entrepreneurial intentions didefinisikan sebagai tindakan-tindakan awal yang dilakukan oleh seseorang sebelum memulai suatu bisnisnya secara formal (Carr dan Sequeiria 2007). Berdasarkan theory of planned behavior yang dikemukakan oleh Ajzen (1991), entrepreneurial intentions merepresentasikan atau mencerminkan usaha yang dilakukan oleh seseorang untuk bertindak atau berperilaku wirausaha (Linan dan Chen 2009).

\section{HIPOTESIS}

Dukungan yang dirasakan oleh seseorang akan berdampak pada tingkat kepercayaan diri yang dimiliki oleh seseorang. Perceived support yang terdiri dari dukungan dari keluarga, teman, pemerintah, dana finansial, serta dari universitas memiliki dampak positif signifikan terhadap entrepreneurial self-efficacy. Dengan kata lain bahwa dukungan yang dirasakan oleh seseorang akan membuatnya semakin percaya diri mengenai kemampuannya dalam menjalankan suatu usaha. Hal ini sesuai dengan penelitian yang dilakukan oleh Byabashaija dan Katono (2011) yang menyatakan bahwa dukungan yang dirasakan oleh seseorang akan meningkatkan self-efficacy atau kepercayaan diri untuk berwirausaha. Maka dari itu :

H1 : perceived support berpengaruh positif terhadap self efficacy

Menurut Saeed, dkk (2014) dikatakan bahwa perceived support akan mempengaruhi niat seseorang untuk berwirausaha. Di dalam penelitiannya, Saeed, dkk. (2014) mengemukakan bahwa ketika seseorang mendapatkan dukungan baik itu berupa pengetahuan, finansial, serta dukungan dari orang-orang yang ada di sekitarnya, akan berdampak pada semakin tertariknya orang tersebut untuk memiliki niat berwirausaha. Maka dari itu : 
Seseorang cenderung untuk mengejar karir yang sesuai dengan kemampuan yang dimilikinya (Sequeria dkk. 2007). Self-efficacy mencerminkan tingkat keyakinan seseorang mengenai kemampuannya dalam menjalankan sesuatu. Beberapa penelitian menemukan hasil bahwa self-efficacy merupakan faktor penting yang dapat mendorong seseorang untuk berwirausaha (Gelderen 2008; Kolvereid 1997; Sequeria dkk. 2007). Maka dari itu :

H3 : self-efficacy berpengaruh positif terhadap niat untuk berwirausaha

Takut akan kegagalan merupakan faktor penghambat seseorang dalam bertindak. Hal ini sesuai dengan apa yang dikatakan oleh Shinnar, dkk (2012) bahwa seseorang akan cenderung mengurungkan niatnya apabila merasa tidak mampu atau takut usahanya berujung pada kegagalan. Dalam konteks wirausaha, takut akan kegagalan merupakan ketakutan seseorang bahwa suatu saat usaha yang didirikannya tidak berjalan sebagaimana mestinya. Maka dari itu:

H4 : Fear of failure berpengaruh negatif terhadap niat untuk berwirasuaha.

\section{METODE PENELITIAN}

Untuk variabel niat berwirausaha, self efficacy menggunakan indikator dari Linan dan Chen (2009). Perceived support adalah dukungan yang dirasakan oleh seseorang yang berasal dari beberapa pihak seperti keluarga, pemerintah, teman, universitas serta dukungan kemudahan memperoleh dukungan finansial. Kemudian untuk variabel fear of failure menggunakan single item dari Shinnar, dkk (2012). Kuesioner didistribusikan kepada mahasiswa aktif S1 Manajamen Fakultas Ekonomi dan Bisnis Universitas Airlangga.

\section{HASIL DAN PEMBAHASAN}

Kuesioner didistribusikan kepada 300 responden, namun yang dapat diproses lebih lanjut sebanyak 254. Hal ini disebabkan karena ada kuesioner yang tidak kembali serta ada kuesioner yang tidak lengkap. Berdasarkan karakteristik responden dalam penelitian ini, sebanyak $54 \%$ dari responden adalah laki-laki, dan sisanya sebesar $46 \%$ adalah perempuan. 


\section{Jovi Sulistiawan}

Kemudian sebagian besar responden saat mengisi kuesioner sedang menempuh semester 6 atau lebih, yaitu sebanyak $48 \%$ dari total responden, sedangkan sisanya merupakan kombinasi dari mahasiswa yang menempuh semester 2 hingga semester 4. Pada saat mengisi kuesioner, sebagian besar responden berusia antara 17-19 tahun, yaitu sebanyak $38 \%$, sedangkan sisanya berada dalam kelompok usia 20-23 tahun. Rata-rata usia responden pada saat mengisi kuesioner adalah 20,2 tahun. Ditinjau dari segi pekerjaan orang tua saat ini, sebagian besar orang tua responden bekerja sebagai wirausahawan, yaitu sebesar $31 \%$. Pada saat pengisian kuesioner, sebagian besar responden masih belum memiliki bidang usaha sendiri, yaitu sebesar $77 \%$, sedangkan $23 \%$ sisanya telah memiliki usaha sendiri yang terdiri dari berbagai macam jenis usaha seperti clothing, event organizer, dan kuliner.

Tabel 1

\begin{tabular}{|l|l|l|}
\hline Independent variabel & Dependent variable-Self Efficacy & Sig \\
\hline Perceived Support & .226 & .000 \\
\hline Constant & 2.517 & .000 \\
\hline R $^{2}$ & .055 & \\
\hline F & 14.656 & .000 \\
\hline
\end{tabular}

Berdasarkan tabel 1 dapat diketahui bahwa perceived support berpengaruh positif terhadap self-efficacy. Hal ini dapat dilihat bahwa nilai signifikansinya kurangdari 0.05 sehingga dapat dikatakan bahwa hipotesis 1 diterima.

Tabel 2

\begin{tabular}{|l|l|l|}
\hline Independent variabel & Dependent variable-entrepreneurial intentions & Sig \\
\hline Perceived Support & .468 & .000 \\
\hline Self-Efficacy & .512 & .000 \\
\hline Fear of failure & -.228 & .000 \\
\hline Constant & .759 & .044 \\
\hline R2 & .386 & \\
\hline F & 52.299 & .000 \\
\hline
\end{tabular}

Berdasarkantabel 2 di atasdapatdiketahuibahwaperceived support, self-efficacy, danfear of failure memilikipengaruhsignifikanterhadapentrepreneurial intention. Dengan kata lain dapatdikatakanbahwahipotesis 2 , hipotesis 3 danhipotesis 4 diterima. 


\section{DISKUSI DAN IMPLIKASI}

Berdasarkan hasil uji statistik dapat diketahui bahwa perceived support yang terdiri dari dukungan dari keluarga, teman, pemerintah, dana finansial, serta dari universitas memiliki dampak positif signifikan terhadap entrepreneurial self-efficacy. Hal ini mengindikasikan bahwa dukungan yang dirasakan oleh seseorang akan membuatnya semakin percaya diri mengenai kemampuannya dalam menjalankan suatu usaha. Hal ini sesuai dengan penelitian yang dilakukan oleh Byabashaija dan Katono (2011) yang menyatakan bahwa dukungan yang dirasakan oleh seseorang akan meningkatkan self-efficacy atau kepercayaan diri untuk berwirausaha.

Kemudian dapat diketahui pula bahwa self-efficacy berpengaruh positif signifikan terhadap niat mahasiswa untuk berwirausaha. Semakin tinggi tingkat kepercayaan diri mahasiswa mengenai kemampuannya untuk mengelola dan menjalankan suatu usaha maka semakin tinggi pula niat mahasiswa untuk berwirausaha. Hasil penelitian ini didukung dengan hasil penelitian sebelumnya yang menyatakan bahwa self-efficacy merupakan predictor penting dalam memprediksi niat mahasiswa untuk berwirausaha. Fear of Failure berpengaruh negatif terhadap niat mahasiswa dalam melakukan berwirausaha. Hal ini sesuai dengan penelitian yang dilakukan oleh Shinnar, dkk (2012) bahwa tingginya tingkat penghindaran terhadap risiko akan membuat seseorang untuk takut mengambil risiko dan cenderung untuk memilih pekerjaan yang lebih pasti ditinjau dari segi pendapatan.

Hasil penelitian ini dapat menjadi masukan bagi pihak universitas yang memang saat ini tengah giat-giatnya menumbuhkan niat mahasiswa untuk berwirausaha. Salah satu cara yang dapat dilakukan oleh pihak Universitas adalah dengan cara memberikan dukungan yang berupa workshop ataupun perkuliahan mengenai wirausaha yang nantinya dapat meningkatkan ide-ide kreatif mahasiswa yang dapat meningkatkan tingkat kepercayaan dirinya. Dengan meningkatnya tingkat kepercayaan diri dari mahasiswa maka niat untuk berwirausaha juga akan semakin tinggi.

Meskpiun demikian, penelitian ini memiliki beberapa keterbatasan. Pertama, menurut Shinnar, dkk (2012) disebutkan bahwa gender yang berbeda akanmemiliki tingkat kepercayaan diri yang berbeda dan niat untuk berwirausaha yang berbeda pula. Maka untuk penelitian di masa mendatang, hendaknya menguji pengaruh perbedaan gender terhadap self-efficacy seseorang. Kemudian keterbatasan yang berikutnya adalah pengambilan data yang bersifat cross section sehingga masih belum bisa meneliti seberapa jauh pengaruh educational support pada saat mahasiswa baru mengikuti perkuliahan dan 


\section{Jovi Sulistiawan}

setelah masa perkuliahan selesai. Maka dari itu hendaknya untuk penelitian selanjutnya dipertimbangkan untuk menggunakan data time series.

\section{DAFTAR PUSTAKA}

Ajzen,Icek. (1991). The Theory of Planned Behavior. Organizational Behavior and Human Resource Processes. 50,179-211.

Byabashaija, W. dan I. Katono. (2011). The Impact of Entrepreneurial Education on Entrepreneurial Attitude and Intention to Start A Business in Uganda. Journal of Developmental Entrepreneurship. Vol 16, no 1, p 127-144.

Carr, J.C., dan J.M. Sequeira (2007). Prior Family Business Exposure as Intergenerational influence and entrepreneurial Intent: A Theory of Planned Behavior Approach. Journal of Business Research. Vol 60, P 1090 - 1098

Gelderen, Marco Van et al. (2008). Explaining Entrepreneurial Intentions by Means of the Theory of Planned Behavior. Career Developmental International.

Kolvereid, Lars. (1997). Prediction of Employment Status Choice Intentions. Entrepreneurship theory and practice.

Linan, Fransisco. Chen, Yi-Wen. (2009). Development and Cross-Cultural Application of a Specific Instrument to Measure Entrepreneurial Intentions. Entrepreneurship Theory and Practice.

Saeed, dkk. (2014). A Multi-Level Study of Entrepreneurship Education among Pakistani University Students.

Shinnar, R.S., dkk (2012). Entrepreneurial Perception and Intention : The Role of Gender and Culture. Entrepreneurship Theory and Practice. P 465-493

Sequeria, J., dkk (2007). The Influence of Social Ties and Self-Efficacy in Forming Entrepreneurial Intention and Motivating Nascent Behavior. Journal of Developmental Entrepreneurship. Vol 12, no 3, p 275-293 